\title{
Incorporating Language Structure in a Communicative Task: An Analysis of the Language Component of a Communicative Task in the LINC Home Study Program
}

Iryna Lenchuk

The purpose of this article is to analyze a task included in the LINC Home Study (LHS) program. LHS is a federally funded distance education program offered to newcomers to Canada who are unable to attend regular LINC classes. A task, in which a language structure (a gerund) is chosen and analyzed, was selected from one instructional module of LHS offered as a demonstration module for the general public. Specifically, the analysis presented in this article focuses on how language structure is integrated into the task. The integration of language structure into the task is assessed against the criteria outlined in the Task-Based Language Teaching and Learning (TBLT) literature and the Canadian Language Benchmarks (CLBS) guidelines. The analysis of the task demonstrates that the presentation of language structure in the task violates the main principle of a meaning-based approach to second language teaching (i.e., task-based instruction) that emphasizes the primacy of meaning over language forms. Considering that LHS is a national program identified as one of the Best Practices in Settlement Services language programs, this article calls for more research on the topic.

L'objectif de cet article est d'analyser une tâche du programme de formation à domicile LINC. Ce programme d'éducation à distance est financé par le gouvernement fédéral et offert aux nouveaux arrivants qui ne peuvent pas assister aux cours LINC réguliers. Nous avons choisi une tâche impliquant l'analyse d'une structure linguistique (un gérondif) d'un module pédagogique du programme qui est offert au grand public comme module de démonstration. Plus précisément, l'analyse présentée dans cet article porte sur l'intégration de la structure langagière dans la tâche. L'intégration est évaluée selon les critères découlant de la littérature sur l'enseignement des langues basés sur les tâches et selon les normes linguistiques canadiennes. L'analyse de la tâche a démontré que la présentation de la structure langagière allait à l'encontre du principe sur lequel s'appuie l'approche de l'enseignement d'une langue seconde axée sur le sens (c'est à dire, basée sur les tâches) et faisant prévaloir le sens sur la forme. Le programme de formation à domicile LINC étant un programme national identifié comme une des pratiques exemplaires en matière de services d'établissement, cet article s'exprime en faveur de recherches plus approfondies à ce sujet. 
Grounded in the cognitive-interactionist approach to second language (L2) learning (Long, 1996; Schmidt, 1995), a task as a pedagogical activity has been introduced into the methodology of L2 teaching. For example, the Canadian Language Benchmarks (CLBs) state that task-based instruction is a meaning-based approach, where learning takes place through meaningful and authentic tasks, the purpose of which is to prepare L2 learners for reallife communication (CCLB, 2013b, pp. 46-47). According to the CLBs, one of the characteristics of a task is that the acquisition of language forms (i.e., grammar, vocabulary, pronunciation) is meaning-driven (CCLB, 2013b, pp. $43-44)$.

The main goal of this article is to investigate the extent to which the principles of task-based instruction are reflected in LINC Home Study (LHS), an online program offered to newcomers to Canada. In particular, this article investigates whether or not the presentation of language structures is guided by one of the principles of the communicative language teaching (CLT) that emphasizes the primacy of meaning over language forms. This article analyzes a task included in Module 4: Family Life of LHS available for the general public as a demonstration module (Centre for Education and Training, 2014). The results of the analysis suggest that (a) the principle of the CLT that emphasizes the primacy of meaning over language form is not observed in the task included in LHS, and (b) LHS utilizes a theoretically and methodologically outdated framework where language forms are presented in isolation from their communicative contexts. The results are surprising considering the fact that LHS is included into the list of language programs under the category of Best Practices in Settlement Services and has been offered as a distance education program in seven provinces in Canada: Alberta, New Brunswick, Newfoundland and Labrador, Nova Scotia, Ontario, Prince Edward Island, and Saskatchewan (Government of Canada, 2012).

The article is structured as follows. The first section defines a task and outlines a set of criteria used to incorporate language structures into a task. The next section provides a description of LHS and one of its instructional modules. The third section discusses the results of analyzing a task against the criteria outlined in the first section. The final section offers conclusions.

\section{Communicative Task as a Consciousness-Raising Activity}

The first question to be raised is "What is a task?" A task is a complex activity that aims to accomplish a number of pedagogical goals. For example, a task that is carefully developed by an ESL textbook writer, curriculum designer, or ESL teacher may target a particular language structure, the acquisition of which is necessary in order to complete a task. Alternatively, a task can be developed to prepare L2 learners for successful communication outside the ESL classroom. Because one task can potentially have different goals, it is difficult to find a single uniform definition of a task. The information presented below 
provides a brief summary of how the concept of task is viewed in the current Task-Based Language Teaching and Learning (TBLT) literature.

1. A task is a classroom activity that promotes meaning and interaction (Willis \& Willis, 2007, p. 11). This definition of a task emphasizes its communicative function and rejects the notion of "focused" or "metacommunicative" tasks. According to Willis and Willis (2001), L2 learners are free to use any language form that is available to them in order to complete a communicative task.

2. The proponents of the so-called "weak" interpretation of a task argue that focus-on-form activities should be incorporated in a task, which can be defined as

a piece of classroom work that involves learners in comprehending, manipulating, and producing or interacting in the target language while their attention is focused on mobilizing their grammatical knowledge in order to express meaning, and in which the intention is to convey meaning rather than to manipulate form. (Nunan, 2004, p. 4)

3. Long and Crookes (1992, p. 43) emphasize the authenticity of a task by stating that a task should emphasize what is done, not what is said. As such, a task should prepare L2 learners for effective communication outside the L2 classroom.

4. Loschky and Bley-Vroman (1993) state that a task should focus learners' attention on language structures. However, language structures should not be presented in isolation; they should be incorporated in a task (Eckerth, 2008, pp. 15-19; Ellis, 2009; Nunan, 2004).

5. A task should have specific outcomes and should be meaningful to L2 learners (Bygate, Skehan, \& Swain, 2001, p. 11).

6. A task should be able to stand alone as a communicative act; it should have a sense of completion and a clear structure with a beginning, middle, and end (Nunan, 2004, p. 4).

Out of the many perspectives on tasks outlined above, one perspective is that tasks can be defined as "'consciousness raising' activities which facilitate the development of grammatical knowledge through hypothesis testing and inferencing" (Rutherford \& Smith, 1988, as cited in Loschky \& Bley-Vroman, 1993, p. 123). Empirical research shows that carefully designed tasks promote the acquisition of language structures, such as question forms (Mackey, 1999) and the forms to express degrees of certainty (Samuda, 2001). If language structures form an important component of a task, then how should they be introduced to L2 learners? The information below summarizes the main principles of incorporating language structures in a task, as outlined in the literature on the TLBT and in the CLBs (CCLB, 2013b, p. 46). 
1. Language structures should not be presented in isolation from their communicative contexts. Meaning is central to a task, and language structures should be used as tools that are necessary for the successful completion of a task. In other words, rather than focusing on one grammatical competence, a task should target a combination of different competences - for example, grammatical and discourse competences (CCLB, 2012).

2. An enhanced comprehensible input should be available (i.e., the target language structures should be present in the input).

3. There should be a focus on a number of related structures within a task. A task should target the acquisition of a number of language structures and not just one presented in isolation from other language structures. For example, in order for an L2 learner to learn how to make polite requests, in addition to modal verbs (i.e., can, could, would), a task should focus on the mechanism of subject-auxiliary inversion and on the use of the main verbs that follow the modal verbs in such requests. Presentation of language structures in isolation reflects an outdated theoretical (i.e., structuralism) and methodological (i.e., audiolingual) approach to language and language learning. In addition, it does not reflect the findings of L2 theoretical and empirical research on how people learn languages and how their interlanguage (IL) grammars develop (Long \& Crookes, 1992).

4. Multiple opportunities should be present to produce structures in meaningful activities (Swain, 1995). If fluency in a task is as important as accuracy, tasks should be designed in a way that $\mathrm{L} 2$ learners receive multiple opportunities to produce targeted structures in a variety of communicative contexts.

For the purpose of this article, the definition of a task and the main principles for incorporating language structures into a task, as presented in this section, have been used as the guiding principles for the analysis of a task in LHS. In particular, in this article, a "weak" interpretation of a task is emphasized (Nunan, 2004). This approach does not exclude activities that focus learners' attention on target vocabulary and language structures; however, a language component is incorporated into a task to achieve specific communicative goals.

The analysis of a task should not be separated from its instructional context. Therefore, the next section provides a brief overview of LHS together with a description of one of its instructional modules (Module 4: Family Life) that incorporates tasks as part of its pedagogical activities.

\section{LINC Home Study: A Brief Overview}

LHS is a federally funded program designed for immigrants and Convention refugees to Canada who are unable to attend regular LINC classes. The fol- 
lowing criteria would qualify a newcomer to Canada to be referred to LHS by an assessor: (a) accessibility (i.e., access to transportation; access to the LINC classroom); (b) the necessity to care for children below the age of 5; (c) illness; or (d) disability. LHS was originally piloted as a distance education program in 1993 in Halton region, Ontario. Currently, LHS is a national distance education program that has been offered in the seven provinces mentioned above (Government of Canada, 2012). In 2010, LHS has 1,200 contracted seats and 75 LINC instructors in the province of Ontario (Ramachandran, Maggio, \& Rosic, 2010).

Being a self-study program, LHS requires a high level of personal commitment and dedication from an L2 learner. The program includes two mandatory components:

- A self-study component (approximately 5-10 hours a week). The program targets the development of the four language skills.

- A 35-minute class held over the phone with an L2 instructor, or a 45-minute lesson for learners with hearing and visual impairment (Ramachandran et al., 2010).

There are seven modules in LHS (Modules 2-7, and a workshop on writing). The modules correspond to LINC levels 2-7. It should be noted that each module has an identical structure across all levels; each module consists of five or six units. Each unit has four identically structured sections: (a) Dialogue, which targets the development of a speaking skill; (b) Reading, which targets the development of a reading skill; (c) Grammar, which targets the development of a grammatical competence; and (d) Coffee Time, which provides an additional listening practice. Table 1 illustrates the organizational structure of Module 4, which is available as a demonstration module for the general public (Centre for Education and Training, 2014). ${ }^{1}$

\section{Analysis of the Language Component of a Task Against the Selected Criteria}

One of the tasks that L2 learners have to complete in Unit 1 is to express an opinion about what an L2 learner enjoys doing in his/her free time (see Dialogue 2 Go D8). ${ }^{2}$ The learner has to state an opinion by answering the following questions: What do you enjoy doing in your free time? With whom do you spend your leisure time? If you had some free time, where would you go? This pedagogical activity can be identified as a task because it is meaning-based, is authentic, and promotes interaction. The following criteria, outlined earlier in this article, are used for the analysis of the language structure included into the task: (a) primacy of meaning over language structures, (b) frequency of the structure (i.e., gerunds) in the input, (c) focus on a number of related structures within a task, and (d) frequency of the structure (i.e., gerunds) in the output. 
Table 1

Organization of the Instructional Module in LHS

\begin{tabular}{|c|c|c|}
\hline Module & Unit & Unit structure \\
\hline \multirow[t]{5}{*}{$\begin{array}{l}\text { Module 4: } \\
\text { Family Life }\end{array}$} & $\begin{array}{l}\text { Unit 1: } \\
\text { Leisure Time }\end{array}$ & $\begin{array}{l}\text { Dialogue (speaking skills): } \\
\text { - prelistening exercises } \\
\text { - dialogue } \\
\text { - practice } \\
\text { Reading (reading skills): } \\
\text { - prereading exercises } \\
\text { - a reading passage } \\
\text { - practice } \\
\text { Grammar (language component; grammatical competence): } \\
\text { - rule } \\
\text { - practice } \\
\text { Coffee Time (speaking skills): } \\
\text { - dialogue } \\
\text { - comprehension questions }\end{array}$ \\
\hline & $\begin{array}{l}\text { Unit 2: } \\
\text { Higher Education }\end{array}$ & Units 2, 3, 4, and 5 have a structure identical to Unit 1. \\
\hline & $\begin{array}{l}\text { Unit 3: Family } \\
\text { Relationships }\end{array}$ & \\
\hline & Unit 4: Employment & \\
\hline & $\begin{array}{l}\text { Unit 5: } \\
\text { A Job Interview }\end{array}$ & \\
\hline
\end{tabular}

\section{Criterion 1: Primacy of Meaning over Language Structures}

As seen in Table 1, the unit is organized so that the language structures (e.g., gerund) required for the successful completion of the task are presented in isolation from their communicative contexts. To illustrate, the task described above is presented in the Dialogue section, whereas the exercises that target the acquisition of a gerund are presented separately in the Grammar section. The structure is presented deductively outside its communicative function. The presentation of the structure starts with the definition of a gerund, where a gerund is defined as "a verb that functions as a noun" (Unit 1, Grammar, G9). This definition could be confusing for L2 learners who do not have immediate access to a language instructor and cannot ask clarification questions because of the nature of a distance education program. The definition could be confusing because it implies that a verb and a noun share similar syntactic functions, which is not quite correct. ${ }^{3}$

The definition of a gerund is followed by a list of its functions. In particular, it is explained that a gerund can function as a subject, an object, and an object of a preposition. Each function is illustrated with one sentence. For example, "A gerund can be used as a subject of a verb," as in Exercising is good for you. L2 learners are also given a list of the verbs that are followed by a 
gerund (i.e., appreciate, avoid, consider, delay, dislike, enjoy, escape, excuse, finish, forgive, imagine, involve, insist, keep, miss, practice, remember, risk, save, suggest, understand).

In general, this section includes grammatical explanations that some L2 learners of LINC Level 4 might find challenging (e.g., grammatical terms such as "function," "subject," "object") in light of the self-study component of LHS. There is no accommodation for individual differences of L2 learners (e.g., L1, education, literacy level, preferences in learning). At times, the grammatical explanation is not supported by examples. As mentioned above, L2 learners are given a list of verbs that are followed by gerunds; however, the examples are given for only 5 out of 21 verbs (avoid, enjoy, remember, suggest, save). Most of the examples are at a sentence rather than discourse level, and there are no references to the communicative context of a dialogue or a reading passage introduced at the beginning of the unit.

As seen from this analysis, the criterion of primacy of meaning over language structures in a task is not observed in LHS. The violation of the criterion implies that LHS may not consistently incorporate into its program the current methodology of the CLT that emphasizes the communicative function of language.

\section{Criterion 2: Frequency of the Structure (i.e., Gerunds) in the Input}

The input is provided to L2 learners through two dialogues (D1 and D2, respectively) and two reading passages (R1 and R2, respectively). The analysis of the Dialogue section demonstrates that only one sentence with a gerund is used in Dialogue 1, where the interlocutors discuss their preferences in movies (Movies are supposed to be about acting, in Going to the Movies, D1). Dialogue 2, where a couple discuss their plans for a weekend trip, has five sentences with a gerund: I don't like travelling. I love exploring. I prefer staying at home, cleaning up the garden. I hate staying home all the time. Marco quit smoking ..., and Lisa never stops talking (Vacation Plans, D5). In Dialogue 2, the gerunds are used as objects of the verbs love, prefer, hate, quit, and stop.

There are two reading passages in the Unit: (a) Reading 1, "The Stars Dazzle in Toronto," is about the Toronto International Film Festival, and (b) Reading 2, "Fan Flabbergasted by Star," is about a phone call made by a movie star to a fan. There are no sentences with a gerund in Reading 1, whereas Reading 2 has one sentence with a gerund (I was a bit surprised but I took a sandwich from him and started eating.)

The analysis of the two sections, Dialogue and Reading, shows that the target structure is not frequently used in the input. As a result, L2 learners are not provided with enough examples that can facilitate noticing of this structure in the input. 


\section{Criterion 3: Focus on a Number of Related Structures Within a Task}

One of the language structures introduced in this unit is gerunds. Gerunds can function as objects of prepositions. This function of gerunds is widely used in communication when the speakers of English talk about their preferences in relations to the activities they like to do in their free time (e.g., I am interested in ... I am excited about ... I am fond of ... I am looking forward to ...). For the purpose of the authenticity of the task, a gerund could have been introduced with the preposition instead of the adjectives and adverbs selected for this unit. The presentation of the gerund together with prepositions would have increased the communicative value and authenticity of the task; in addition to gerunds, L2 learners would then have had an opportunity to acquire prepositions. (It is known from classroom observations and empirical research on the acquisition of prepositions that learning prepositions constitutes a major challenge for L2 learners; Jarvis \& Odlin, 2000).

To summarize, the main problem with the incorporation of a language component in a task as organized in LHS is that language structures are presented in isolation from each other (i.e., one structure at a time) and from the communicative context of the task. When structures are presented in isolation, it makes it difficult for L2 learners to understand the purpose of learning the structures and, most importantly, how the structures can be used for the successful completion of a task.

\section{Criterion 4: Frequency of the Structure (i.e., Gerunds) in the Output}

According to this criterion, L2 learners should be provided with a series of communicative activities. These activities provide L2 learners with multiple opportunities to practice the language structure that they need for the successful completion of a task. Each LHS module has four practice exercises that target the acquisition of gerunds. In Exercise 1, L2 learners are asked to replace an underlined word or an expression with a matching gerund. For example, in the sentence Exercise will keep you healthy, the underlined word exercise should be replaced with the gerund exercising. In the sentence Ballet develops muscles, the underlined word ballet should be replaced with the gerund dancing. In Exercise 2, L2 learners are given five sentences with the verbs can't stand, detest, enjoy, love, hate, avoid. The verbs in these sentences are followed by gerunds. L2 learners are asked to identify the gerund that functions as an object in the following sentences:

1. I enjoy watching old movies in the evening.

2. Lucy likes reading on quiet, Sunday afternoon.

3. Jacob loves playing chess with his friends.

4. Mary hates swimming in the pool.

In Exercise 3, L2 learners are asked to write three sentences about some of the things they enjoy doing (e.g., I enjoy studying English grammar), and submit 
the sentences as homework. In Exercise 4, L2 learners are asked to arrange the words that are provided to them in five questions. For example, the words Do, you, the enjoy, newspaper?, reading should be organized into the question Do you enjoy reading the newspaper? There are four yes/no questions and one wh-question. In Exercise 5, L2 learners are asked to complete four sentences with the gerunds writing, saving, wearing, swimming. For example, My favourite sport is

One thing I enjoy is new clothes.

The target structure in the exercises is gerunds; thematically, the sentences in the practice exercises express (a) a general statement/opinion (see Exercise 1 above), (b) the description of a preferred leisure activity (see Exercise 2 above), and (c) the description of likes and dislikes (see Exercises 3 and 5 above). Undoubtedly, some of the exercises (e.g., Exercise 2) can provide L2 learners with practice in the target form, which is necessary for the successful completion of the task. However, in terms of production, L2 learners are not provided with enough tokens of the target form that would allow them to obtain a better control over the structure (i.e., only three tokens in Exercise 3 and four tokens in Exercise 5). In addition, all the practice exercises target the structure at the sentence level and there are no practice exercises where L2 learners learn how to integrate the structure with other competences (i.e., discourse). (For some tentative suggestions on how the module can be organized, please see Appendix A and Appendix B).

\section{Conclusion}

The mandate of LHS is to provide language training services to L2 learners who cannot attend regular LINC classes. This mandate reflects the principles of accessibility, accommodation, and inclusiveness for all learners that are emphasized in current educational practices. However, it is surprising to find that the analyzed task included in the instructional unit of LHS does not reflect the findings of the current research on L2 teaching and learning (i.e., task-based instruction) and, as such, is not guided by the CLBs. In particular, the analysis presented in this article indicates that the main principle of the task-based instruction that emphasizes meaning over language forms in not observed in the task. Needless to say, more research is needed to investigate the language component of LHS and its integration into communicative tasks.

\section{Notes}

1. The demonstration module (Module 4: Family Life) is accessible thorough the home page of LHS (Centre for Education and Training, 2014). One can access the module by logging in with the User ID and password demo.

2. Dialogue 2 Go D8 can be found by following these steps: (a) open the home page of the LHS (Center for Education and Training, 2014); (b) log in with the following User ID and password: 
demo; (c) choose Module 4: Family Life under the heading My Courses; (d) choose Unit 1 and the section Dialogue from the menu on the left; (e) choose the option D8 under the heading Dialogue Overview.

3. The definition of a gerund is still under discussion, and it is not quite clear whether it should be categorized as a noun or as a verb (see, e.g., Huddleston \& Pullum, 2002, pp. 81-83). A better way to present a gerund to $\mathrm{L} 2$ learners would be in a communicative context (i.e., a dialogue or a reading passage) that would model the task that $\mathrm{L} 2$ learners have to complete. However, if an explicit explanation is indeed needed, it should state that a gerund is similar to a verb because it is derived from a verb; a gerund is also similar to a noun because it can function as a subject, an object, and an object of a preposition.

\section{Acknowledgements}

I would like to thank the two anonymous reviewers for many insightful comments and suggestions on a previous draft of this article. Their suggestions have greatly improved both the form and the content of the article. I would also like to thank the participants of the Canadian Association of Applied Linguistics Annual Conference, Brock University, St. Catharines, Ontario, for their comments on a previous draft. Any remaining errors are my own.

\section{The Author}

Iryna Lenchuk is a PhD candidate in the Linguistics and Applied Linguistics program, York University, Toronto, Ontario. She has more than 10 years of experience teaching ESL in federally funded programs in Ontario. She is also a part-time TESL instructor at the Faculty of Continuing Education and Training, Seneca College, Toronto, Ontario.

\section{References}

Bygate, M., Skehan, P., \& Swain, M. (Eds.). (2001). Researching pedagogic tasks: Second language learning, teaching, and testing. London, UK: Longman.

Centre for Canadian Language Benchmarks (CCLB). (2012). Canadian Language Benchmarks: English as a second language for adults. Retrieved from http://www.cic.gc.ca/english/pdf/pub/ language-benchmarks.pdf

Centre for Canadian Language Benchmarks (CCLB). (2013a). Canadian Language Benchmarks: Can do statements. Retrieved from http://www.language.ca/documents/CLB_Can_Do_ Statements_web.pdf

Centre for Canadian Language Benchmarks (CCLB). (2013b). Theoretical framework. Retrieved from http://www.language.ca/documents/theoretical_framework_web.pdf

Centre for Education and Training. (2014). LINC home study. Retrieved from https://www.linc homestudy.ca/Online/

Eckerth, J. (2008). Task-based language learning and teaching: Old wine in new bottles? In J. Eckerth \& S. Siekmann (Eds.), Task-based language learning and teaching (pp. 13-46). New York, NY: Peter Lang.

Ellis, R. (2009). Task-based language teaching: Sorting out the misunderstandings. International Journal of Applied Linguistics, 19(3), 222-246.

Government of Canada. (2012). LINC home study. Retrieved from http://www.cic.gc.ca/english/ department/partner/bpss/LINChome.asp

Huddleston, R., \& Pullum, G. K. (Eds.). (2002). The Cambridge grammar of the English language. Cambridge, UK: Cambridge University Press.

Jarvis, S., \& Odlin, T. (2000). Morphological type, special reference, and language transfer. Studies in Second Language Acquisition, 22(4), 535-556.

Long, M. H. (1996). The role of linguistic environment in second language acquisition. In W. C. Ritchie \& T. K. Bhatia (Eds.), Handbook of second language acquisition (pp. 413-468). New York, NY: Academic Press. 
Long, M. H., \& Crookes, G. (1992). Three approaches to task-based syllabus design. TESOL Quarterly, 26(1), 27-56.

Loschky, L., \& Bley-Vroman, R. (1993). Grammar and task-based methodology. In G. Crookes \& S. M. Gass (Eds.), Tasks and language learning: Integrating theory and practice (pp. 123-167). Clevedon, UK: Multilingual Matters.

Mackey, A. (1999). Input, interaction, and second language development: An empirical study of question formation in ESL. Studies in Second Language Acquisition, 21(4), 557-587.

Nunan, D. (2004). Task-based language teaching. Cambridge, UK: Cambridge University Press.

Ramachandran, S., Maggio, E., \& Rosic, I. (2010, October). Language education at a distance: LINC home study. Conference/webcast. Retrieved from <http://www.snwebcastcenter.com/custom_events/tesl-2010-fas/site/player_wm_archive.php>http://www.snwebcastcenter.com/ custom_events/tesl-2010-fas/site/player_wm_archive.php

Samuda, V. (2001). Guiding relationships between form and meaning during task performance: The role of the teacher. In M. Bygate, P. Skehan, \& M. Swain (Eds.), Researching pedagogic tasks: Second language learning, teaching and testing (pp. 119-140). London, UK: Longman.

Schmidt, R. (1995). Consciousness and foreign language learning: A tutorial on the role of attention and awareness in learning. In R. Schmidt (Ed.), Attention and awareness in foreign language learning (pp. 1-63). Honolulu, HI: National Foreign Language Resource Center, University of Hawaii.

Swain, M. (1995). Three functions of output in second language learning. In G. Cook \& B. Seidlhofer (Eds.), Principles and practice in applied linguistics: Studies in honour of H. G. Widdowson (pp. 125-144). New York, NY: Oxford University Press.

Toronto Catholic District School Board. (2002). LINC 1-5 curriculum guidelines. Retrieved from http://www.settlement.org/downloads/linc/LCG1 to5/themes.htm

Willis, D., \& Willis, J. (2001). Task-based language learning. In R. Carter \& D. Nunan (Eds.), The Cambridge guide to teaching English to speakers of other languages (pp. 173-179). Cambridge, UK: Cambridge University Press.

Willis, D., \& Willis, J. (2007). Doing task-based teaching. Oxford, UK: Oxford University Press.

\section{Appendix A \\ Components of an Instructional Module}

(The ideas expressed in Appendix A and Appendix B present tentative suggestions as to what can be included in an instructional module of LHS so that it follows the guidelines outlined in the CLBs and in the current TBLT literature.)

1. Themes and topics of the instructional modules should correspond to those recommended in the LINC Curriculum Guidelines (Toronto Catholic District School Board, 2002).

2. LHS emphasizes the development of the four skills; therefore, a module should be structured around the four skills and should target specific competency areas (e.g., reading: comprehending information, listening: interacting with others). The Grammar section, which presents language forms in isolation from their contexts, should be removed from a unit.

3. Module outcomes should be task-based and CLB-based. For example, the outcome of understanding and using gerunds (Centre for Education and Training, 2014) is not a target-based outcome. Alternatively, a task-based and a CLB-based outcome can be expressed as follows: in this module, a 
learner will learn how to "listen to a friend or co-worker describing plans for the weekend" (CCLB, 2012, p. 10). The objectives and activities present in a module should correspond to the profile of the ability of a learner listed in the CLBs.

4. Exercises on grammar and vocabulary should be incorporated into activities that target the development of a competency area in a language skill. There should be a variety of controlled and free exercises that would allow for recycling vocabulary and grammar.

5. Self-assessment (e.g., Can Do Statements; CCLB, 2013a) can be included in each instructional module as part of an ongoing, formative assessment.

\section{Appendix B \\ A Sample of a Module (Stage I - Basic Language Ability [CCLB, 2012, X])}

\begin{tabular}{|c|c|c|c|}
\hline Module & $\begin{array}{l}\text { Targeted } \\
\text { competency } \\
\text { area (as pre- } \\
\text { sented to an } \\
\text { ESL instruc- } \\
\text { tor) }\end{array}$ & $\begin{array}{l}\text { Outcomes (as } \\
\text { presented to an } \\
\text { L2 learner) } \\
\text { Sample tasks }\end{array}$ & $\begin{array}{l}\text { Procedures } \\
\text { (for the purpose of this article, the proce- } \\
\text { dures are developed only for a reading } \\
\text { task) }\end{array}$ \\
\hline $\begin{array}{l}\text { Module: } \\
\text { At Home } \\
\text { in Our } \\
\text { Commu- } \\
\text { nity and } \\
\text { the World } \\
\text { Unit 1: } \\
\text { Finding a } \\
\text { place to } \\
\text { live } \\
\text { Unit 2: } \\
\text { Neigh- } \\
\text { bours and } \\
\text { Neigh- } \\
\text { bourhoods }\end{array}$ & $\begin{array}{l}\text { Speaking } \\
\text { (targeted } \\
\text { competency } \\
\text { area: inter- } \\
\text { acting with } \\
\text { others) }\end{array}$ & $\begin{array}{l}\text { In this unit, you } \\
\text { will learn how to } \\
\text { read a very } \\
\text { simple, short } \\
\text { description of an } \\
\text { apartment or a } \\
\text { house; }\end{array}$ & $\begin{array}{l}\text { This unit should prepare L2 learners to } \\
\text { read a simple description of an apartment } \\
\text { or a house. It should prepare them for the } \\
\text { authentic activity of reading rental ads. } \\
\text { 1. The unit starts with a reading task that } \\
\text { can incorporate prereading, reading, and } \\
\text { postreading activities. } \\
\text { A prereading activity introduces new vo- } \\
\text { cabulary. For example, basement (noun), } \\
\text { the lowest floor in the building, can be } \\
\text { underground. Example: Many students } \\
\text { rent basements. The rent for a basement } \\
\text { is cheap. Introducing new vocabulary can } \\
\text { be combined with exercises on pronuncia- } \\
\text { tion. } \\
\text { A reading activity: read a very simple, } \\
\text { short description of an apartment or a } \\
\text { house that incorporates new vocabulary. } \\
\text { A postreading activity includes a number } \\
\text { of exercises for comprehension (e.g., } \\
\text { matching the correct description of an } \\
\text { apartment or a house with a picture). }\end{array}$ \\
\hline
\end{tabular}




\begin{tabular}{|c|c|c|}
\hline $\begin{array}{l}\text { Writing } \\
\text { (targeted } \\
\text { competency } \\
\text { area: sharing } \\
\text { information) }\end{array}$ & $\begin{array}{l}\text { write a simple } \\
\text { description } \\
\text { of your home } \\
\text { by answering } \\
\text { a short list of } \\
\text { questions pro- } \\
\text { vided on a work- } \\
\text { sheet }\end{array}$ & $\begin{array}{l}\text { 2. Language focus: structures that are } \\
\text { required for a successful completion of } \\
\text { the task of reading a very simple, short } \\
\text { description of an apartment or a house. In } \\
\text { this case, structures, such as "to be," "to } \\
\text { have," "the," "a," number (SG and PL). } \\
\text { For example, This is a big apartment. This } \\
\text { apartment has two bedrooms. The apart- } \\
\text { ment has a big balcony. It is on the third } \\
\text { floor. } \\
\text { Because this module targets beginners, } \\
\text { the L2 learners may benefit from multiple } \\
\text { exposures to the target structures rather } \\
\text { than from an explicit rule in a metalan- } \\
\text { guage that the learners may not under- } \\
\text { stand. The learners can benefit from a } \\
\text { number of reading and listening passages } \\
\text { that include the target structures and have } \\
\text { one common theme. }\end{array}$ \\
\hline
\end{tabular}

